\title{
ChemComm
}

Check for updates

Cite this: Chem. Commun., 2020, 56, 13401

Received 27th August 2020,

Accepted 5th October 2020

DOI: $10.1039 / \mathrm{d} 0 \mathrm{cc} 05816 \mathrm{e}$

rsc.li/chemcomm

\section{Titanium methyl tamed on silica: synthesis of a well-defined pre-catalyst for hydrogenolysis of $\boldsymbol{n}$-alkane $\dagger$}

\author{
Aya Saidi, (D) ${ }^{a}$ Walid Al Maksoud, ${ }^{a}$ Manoja K. Samantaray, (D) *a Edy Abou-Hamad (D) ${ }^{b}$ \\ and Jean-Marie Basset (D)*a
}

\begin{abstract}
Alkylation of $\mathrm{Ti}\left(\mathrm{CH}_{3}\right)_{2} \mathrm{Cl}_{2} 1$ by MeLi gives the homoleptic $\mathrm{Ti}\left(\mathrm{CH}_{3}\right)_{4}$ 2 for the first time in the absence of any coordinating solvent. The reaction of 2 with silica pretreated at $700{ }^{\circ} \mathrm{C}\left(\mathrm{SiO}_{2-700}\right)$ gives two inequivalent silica-supported Ti-methyl species 3. Complex 3 was characterized by IR, microanalysis (ICP-OES, CHNS, and gas quantification), and advanced solid-state NMR spectroscopy $\left({ }^{1} \mathrm{H},{ }^{13} \mathrm{C}, \mathrm{DQ}, \mathrm{TQ}\right.$, and HETCOR). The catalytic activity of the precatalyst 3 is investigated in low-temperature hydrogenolysis of propane and $n$-butane with TONs of 419 and 578, respectively.
\end{abstract}

Conversion of inexpensive waxes, generated from the FischerTropsch process to valuable chemicals/fuels, is a value-added process. ${ }^{1}$ Mainly, the hydrocracking process was used for the cracking of paraffinic waxes into useful chemicals. ${ }^{2,3}$ The primary obstacles in this process are the high temperature of reaction and the fast deactivation of the catalyst with the formation of coke. ${ }^{4}$ Many efforts were undertaken to reduce the temperature and carry out the conversion of waxes to valuable chemicals effectively. ${ }^{5}$ Since the discovery of the well-defined silica-supported $\mathrm{Zr}$ hydride, $\left[(\equiv \mathrm{Si}-\mathrm{O})_{3} \mathrm{ZrH}\right]$, which was able to catalyze the hydrogenolysis of a given alkane to lower homologs and the de-polymerization (Ziegler-Natta depolymerization) of LLDPE to fuel range alkanes at relatively low temperature $\left(150{ }^{\circ} \mathrm{C}\right)$, a new door was opened up for research in this new field. ${ }^{6,7}$

Recently, we observed that moving from metal neopentyl to metal methyl, the reactivity in alkane metathesis reaction increased several-fold. ${ }^{8}$ Additionally, it was comparatively easy to characterize the catalyst and understood the possible reaction mechanism by either DFT or by isolating the active

\footnotetext{
${ }^{a}$ King Abdullah University of Science \&Technology, Physical Science and Engineering, KAUST, Thuwal, 23955-6900, Saudi Arabia. E-mail: jeanmarie.basset@kaust.edu.sa, manoja.samantaray@kaust.edu.sa

${ }^{b}$ Imaging and Characterization Core Lab, King Abdullah University of Science and Technology, KAUST, Thuwal, 23955-6900, Saudi Arabia

$\dagger$ Electronic supplementary information (ESI) available. See DOI: 10.1039/ d0cc05816e
}

intermediate by isotopically labeling the methyls attached to metal center. ${ }^{9,10}$ In this regard, we utilized various homoleptic metal methyl homogeneous complexes, which are very rare, very reactive in the homogeneous phase, and almost not suitable for catalysis because of their unstable nature at room temperature. ${ }^{11-14}$ To make them stable for catalysis, we used Surface Organometallic Chemistry (SOMC) approach, which stabilizes molecular species otherwise unstable in solution. Metal alkyl can react with surface silanols and form a stable catalyst at room temperature, which makes them comparatively easier to use for catalysis. ${ }^{11,15}$

Herein, we disclose for the first time the synthesis and characterization of a homoleptic $\operatorname{Ti}\left(\mathrm{CH}_{3}\right)_{4}$ complex, its grafting on silica partially dehydroxylated at $700{ }^{\circ} \mathrm{C}\left(\mathrm{SiO}_{2-700}\right)$, characterization of the grafted material, and its application in hydrogenolysis of propane and $n$-butane.

Synthesis of an ether bound $\left(\mathrm{Et}_{2} \mathrm{O}\right) \mathrm{Ti}\left(\mathrm{CH}_{3}\right)_{4}$ without sufficient proof is already known in the literature, ${ }^{16,17}$ but for our catalytic purposes, we wanted a homoleptic Ti without any coordination of the solvent as the coordinated solvent makes them less electropositive and eventually less effective for $\mathrm{C}-\mathrm{H}$ bond activation. The difficulty in preparing such metal complexes is already reported in the literature, ${ }^{18,19}$ only partial methylated species of metals of group 4 are known so far. ${ }^{20-22}$ Therefore, we choose a soluble metal precursor $\left(\mathrm{TiCl}_{4}\right)$ and a non-coordinated solvent (pentane and dichloromethane) for this reaction. It appeared that the reaction was not straightforward and required two steps (Scheme 1).

In the first step, the $\mathrm{TiCl}_{4}$ precursor is reacted with one equivalent of $\mathrm{Zn}\left(\mathrm{CH}_{3}\right)_{2}$ in a mixture of pentane and dichloromethane $(1 / 1)$ at a temperature range between $-80{ }^{\circ} \mathrm{C}$ to $-40{ }^{\circ} \mathrm{C}$ for 4 hours to yield an orange solution of $\mathrm{TiCl}_{2}\left(\mathrm{CH}_{3}\right)_{2} \cdot{ }^{16}$ In the end, the reaction mixture was filtered, and the filtrate was dried under vacuum. An aliquot of $\mathrm{TiCl}_{2}\left(\mathrm{CH}_{3}\right)_{2}$ was taken in an NMR tube and was mixed with $\mathrm{CD}_{2} \mathrm{Cl}_{2}$ and analyzed by liquid-state NMR $\left({ }^{1} \mathrm{H},{ }^{13} \mathrm{C}\right.$, HSQC, and $\left.{ }^{35} \mathrm{Cl}\right)$ at $-40{ }^{\circ} \mathrm{C} .{ }^{1} \mathrm{H}$ and ${ }^{13} \mathrm{C}$ NMR spectra (Fig. S1A and B, ESI $\dagger$ ) display peaks at $2.6 \mathrm{ppm}$ 


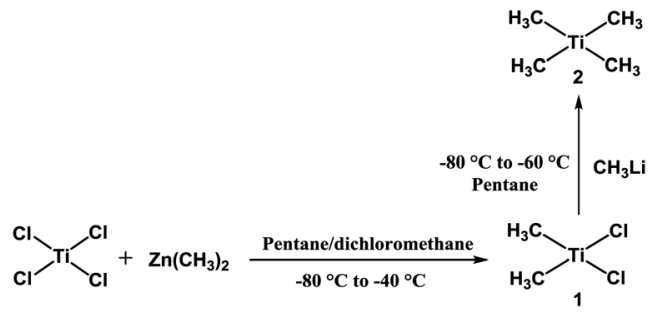

Scheme 1 Synthesis of $\mathrm{TiCl}_{2}\left(\mathrm{CH}_{3}\right)_{2} 1$ and $\mathrm{Ti}_{(}\left(\mathrm{CH}_{3}\right)_{4} 2$.

and $99.1 \mathrm{ppm}$, respectively, attributed to the hydrogen and carbon atoms of the methyl group of $\mathrm{Ti}-\mathrm{CH}_{3}$. This was further proved by the correlation between both of the peaks observed in the HSQC spectrum (Fig. S1C, ESI $\dagger$ ). Additionally, ${ }^{35} \mathrm{Cl}$ NMR was conducted, and a peak at $601.1 \mathrm{ppm}$ confirms the presence of Ti-Cl (Fig. S1D, ESI $\dagger$ ). ${ }^{23-25}$

In the second step, the $\mathrm{TiCl}_{2}\left(\mathrm{CH}_{3}\right)_{2}$ reacted with an excess of $\mathrm{MeLi}$ (50\% enriched) in pentane at a temperature range between $-80{ }^{\circ} \mathrm{C}$ to $-60{ }^{\circ} \mathrm{C}$ for 3 hours, affording a red color solution of the desired product $\operatorname{Ti}\left(\mathrm{CH}_{3}\right)_{4}$ (Scheme 1). The complex is highly sensitive to oxygen, moisture, and temperature; black fumes were observed immediately when the temperature was increased above $-60{ }^{\circ} \mathrm{C}$, which makes it very difficult to isolate the complex. Therefore, at the end of the reaction, the reaction mixture is filtered and used immediately for grafting on oxide surfaces.

In an NMR tube, $0.2 \mathrm{~mL}$ of $\mathrm{TiCl}_{4}$ mixed with one equivalent of $\mathrm{ZnMe}_{2}$, pentane, and $\mathrm{CD}_{2} \mathrm{Cl}_{2}$ at $-80{ }^{\circ} \mathrm{C}$ and let the reaction to run for 1 hour, then an excess of ${ }^{13} \mathrm{C}$ enriched MeLi was added to it, and the reaction continued in the NMR tube for another 3 hours at $-60{ }^{\circ} \mathrm{C}$. The progress of the reaction was analyzed by liquid-state NMR $\left({ }^{1} \mathrm{H},{ }^{13} \mathrm{C}\right.$, and $\left.{ }^{35} \mathrm{Cl}\right)$. In the ${ }^{1} \mathrm{H}$ and ${ }^{13} \mathrm{C}$ NMR spectra (Fig. 1A and B), we observed that the peaks of the ${ }^{1} \mathrm{H}$ and ${ }^{13} \mathrm{C}$ were shifted from 2.6 and $99.1 \mathrm{ppm}$ (as observed in the case of $\left.\mathrm{TiCl}_{2}\left(\mathrm{CH}_{3}\right)_{2}\right)$ to 1.99 and $72.9 \mathrm{ppm}$, respectively, for the newly formed $\mathrm{Ti}\left(\mathrm{CH}_{3}\right)_{4}$ complex. This is understandable as complete alkylation occurs on the Ti center causes an upfield shift of the carbon and proton peaks of methyl ligands. The attribution of the obtained chemical shifts in the liquid-state NMR is realized by comparing them with those of the reported ether bound methyl titanium chlorides. ${ }^{16,26}$

To confirm the complete substitution of chlorine atom by methyl ligand, we characterize the sample by ${ }^{35} \mathrm{Cl}$ NMR (Fig. S2, ESI $\dagger$ ). The ${ }^{35} \mathrm{Cl}$ spectrum of the complex does not show any chlorine peak (which usually comes in between 500-800 ppm

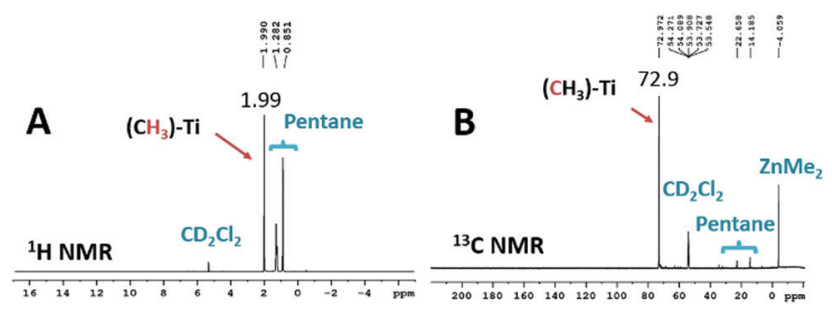

Fig. 1 (A) ${ }^{1} \mathrm{H}$ and (B) ${ }^{13} \mathrm{C}$ NMR spectra of $\mathrm{Ti}_{(}\left(\mathrm{CH}_{3}\right)_{4}$ in $\mathrm{CD}_{2} \mathrm{Cl}_{2}$ at $213 \mathrm{~K}$.

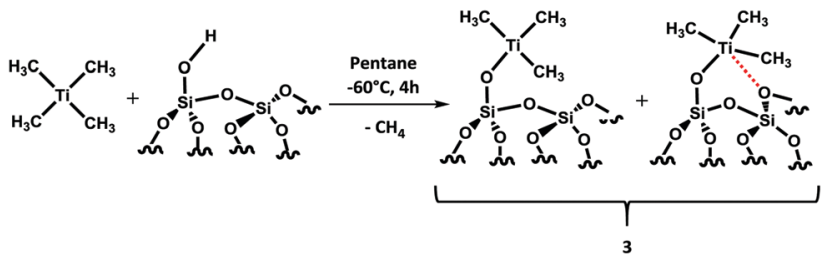

Scheme 2 Reaction of $\mathrm{Ti}\left(\mathrm{CH}_{3}\right)_{4}$ with silica-700 at $-60{ }^{\circ} \mathrm{C}$.

depending upon the number of chlorine atoms attached to $\mathrm{Ti}^{23,24,27}$ ) except that of the deuterated solvent $\mathrm{CD}_{2} \mathrm{Cl}_{2}$. This further corroborates the successful synthesis of a homoleptic $\mathrm{Ti}\left(\mathrm{CH}_{3}\right)_{4}$ complex without any coordinated solvent.

Grafting of $\mathrm{Ti}\left(\mathrm{CH}_{3}\right)_{4}$ was performed in situ by reacting an excess of 2 with partially dehydroxylated silica (silica pretreated at $\left.700{ }^{\circ} \mathrm{C}, \mathrm{SiO}_{2-700}\right)$ at $-60{ }^{\circ} \mathrm{C}$ in pentane under an inert atmosphere of argon for 4 hours (Scheme 2), followed by washing with pentane three times to remove the excess of 2 before drying under high vacuum $\left(10^{-5} \mathrm{mbar}\right)$. In the end, a dark brown powder was obtained. The grafting process generates the formation of two environmentally different $[(\equiv \mathrm{Si}-\mathrm{O}-)$ $\mathrm{TiMe}_{3}$ ] species resulting in the interaction with the silanol groups and $\mathrm{Si}-\mathrm{O}-\mathrm{Si}$ bridges (Scheme 2). As expected, from previous work carried out with $\mathrm{WMe}_{6} /$ silica, once grafted, the Ti complex is much more stable and prone to more in-depth characterization. ${ }^{28,29}$

The grafted complex 3 was characterized by FT-IR spectroscopy, elemental analysis, methane quantification, and solid-state NMR spectroscopy $\left({ }^{1} \mathrm{H},{ }^{13} \mathrm{C}\right.$, DQ, TQ, and HETCOR). The FTIR spectrum was recorded at $25{ }^{\circ} \mathrm{C}$ (Fig. S3, ESI $\dagger$ ); the IR peak of the isolated silanols at $3747 \mathrm{~cm}^{-1}$ completely disappeared, and groups of new bands appeared in 3005-2819 and $1454 \mathrm{~cm}^{-1}$ region. These bands are respectively assigned to the $\nu_{(\mathrm{CH})}$ and $\delta_{(\mathrm{CH})}$ vibrations of the methyl ligands coordinated to titanium. Elemental analysis of 3 was conducted and it gave $1.8 \% \mathrm{Ti}, 1.3 \% \mathrm{C}$ and $0.33 \% \mathrm{H}$, with a ratio of $\mathrm{C} / \mathrm{Ti}=2.88$ and $\mathrm{H} / \mathrm{Ti}=8.77$. These results further prove the formation of complex $\mathbf{3}$.

Furthermore, the structure of $\mathbf{3}$ was characterized by solidstate NMR spectroscopy. The ${ }^{1} \mathrm{H}$ magic-angle spinning (MAS) NMR spectrum of 3 displays one signal at $2.0 \mathrm{ppm}$ (Fig. 2A) that autocorrelated on the diagonals of both double-quantum (DQ) and triple-quantum (TQ) NMR spectra at 4.0 and $6.0 \mathrm{ppm}$, respectively (Fig. 2B and C) which proves that they refer to $-\mathrm{CH}_{3}$ group. The ${ }^{13} \mathrm{C}$ cross-polarization magic-angle spinning (CP-MAS) NMR spectrum shows a main peak at $76 \mathrm{ppm}$ along with a small signal at 61 ppm (Fig. 2D) that correlate with the proton at $2 \mathrm{ppm}$ as indicated in the $2 \mathrm{D}{ }^{1} \mathrm{H}^{1}{ }^{13} \mathrm{C}$ HETCOR NMR spectrum (Fig. 2E). These peaks are assigned to the carbon of the methyl of the titanium species 3 (both with and without interaction with the oxygen atom of the siloxane bridge). This type of interaction was already reported by our group with well-defined $\left[(\equiv \mathrm{Si}-\mathrm{O}-) \mathrm{TaCl}_{2} \mathrm{Me}_{2}\right]$ species. ${ }^{29}$ The ${ }^{13} \mathrm{C}$ signal in solid-state NMR is slightly shifted compared to the carbon peak in the solution NMR spectrum from 72.9 to $76 \mathrm{ppm}$; this is understandable as we have replaced at least one methyl group with an electronegative oxygen atom. 


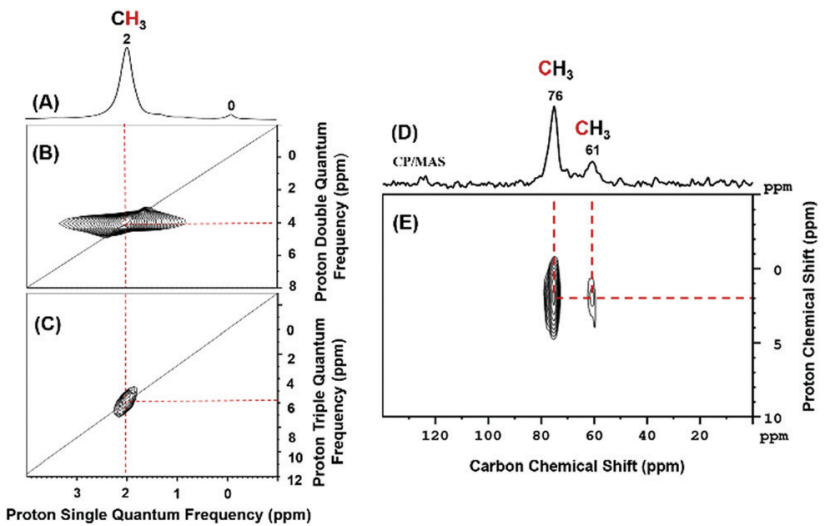

Fig. 2 Solid-state NMR characterization of grafted $\mathrm{Ti}\left(\mathrm{CH}_{3}\right)_{4}$ onto $\mathrm{SiO}_{2-700 \text {; }}$; (A) one-dimensional (1D) ${ }^{1} \mathrm{H}$ MAS solid-state NMR spectrum of $\mathbf{3}$ (acquired on a $600 \mathrm{MHz}$ NMR spectrometer (14.1 T) with a $22 \mathrm{kHz}$ MAS spinning frequency, a repetition delay of $5 \mathrm{~s}$, and 8 scans), (B) two-dimensional (2D) ${ }^{1} \mathrm{H}-{ }^{1} \mathrm{H}$ double-quantum (DQ) spectrum of 3 , (C) two-dimensional (2D) ${ }^{1} \mathrm{H}-{ }^{1} \mathrm{H}$ triple-quantum (TQ) spectrum of 3 (acquired on a $600 \mathrm{MHz} \mathrm{NMR}$ spectrometer at $22 \mathrm{kHz}$ MAS spinning frequency with a back-to-back recoupling sequence, number of scans 128 , repetition delay $5 \mathrm{~s}$, number of t1 increments 128), (D) ${ }^{13} \mathrm{C}$ CP/MAS NMR spectrum of 3 (acquired on a $400 \mathrm{MHz}$ NMR spectrometer $(9.4 \mathrm{~T}$ ) with a $10 \mathrm{kHz}$ MAS frequency, $20 \mathrm{~K}$ scans, a $4 \mathrm{~s}$ repetition delay, and a $2 \mathrm{~ms}$ contact time. Exponential line broadening of $80 \mathrm{~Hz}$ was applied before Fourier transformation), (D) 2D ${ }^{1} \mathrm{H}-{ }^{13} \mathrm{C}$ CP/MAS dipolar HETCOR spectrum of 3 (acquired on a $400 \mathrm{MHz}$ NMR spectrometer (9.4 T) with a $10 \mathrm{kHz}$ MAS frequency, 2048 scans per $t_{1}$ increment, a $4 \mathrm{~s}$ repetition delay, 64 individual $t_{1}$ increments and a $0.2 \mathrm{~ms}$ contact time).

Additionally, the structure of 3 was confirmed by the gas quantification method after hydrolysis. The hydrolysis reaction of $50 \mathrm{mg}$ of complex 3 using degassed water produced $0.937 \mathrm{mmol} \mathrm{g}^{-1}$ of methane; theoretically, we should get $1.065 \mathrm{mmol} \mathrm{g}^{-1}$, which is consistent with the formation of $\left[\left(\equiv \mathrm{SiO}_{-}\right) \mathrm{TiMe}_{3}\right]$ surface species.

After the characterization of complex 3 , it was tested for hydrogenolysis of propane and $n$-butane. In a typical experiment, complex $3(0.088 \mathrm{mmol}$ of Ti) was loaded in a continuous flow reactor, and a mixture of propane or $n$-butane $\left(3.5 \mathrm{~mL} \mathrm{~min}^{-1}\right)$ and hydrogen $\left(9 \mathrm{~mL} \mathrm{~min}^{-1}\right)$ was passed through the catalytic bed at $180{ }^{\circ} \mathrm{C}$. All the reactions were conducted at the atmospheric pressure $(P=1 \mathrm{bar})$. The conversion of the reactant and the gas products were analyzed every $20 \mathrm{~min}$ by on-line gas chromatography.

We achieved a maximum conversion of $85.9 \%$ after $40 \mathrm{~min}$ and a TON of 419 for propane hydrogenolysis and maximum conversion of $99.8 \%$ and a TON of 578 for $n$-butane hydrogenolysis at our contact time (Fig. 3A and B).

During the hydrogenolysis reaction of propane, we observed that the selectivities of methane and ethane remain similar (50:50) (Fig. 3C), which corroborates the previously reported results that $\beta$-methyl transfer is only possible in the case of $\mathrm{Ti}^{30}$ whereas, in the case of $n$-butane, methane, ethane, and propane (Fig. 3D) were observed. From the previously reported data, we know that hydrogenolysis can take place either by $\alpha$-alkyl or $\beta$-alkyl migration, depending on the metal atom. ${ }^{31,32}$ Our results indicate that in our catalytic system, we only observe
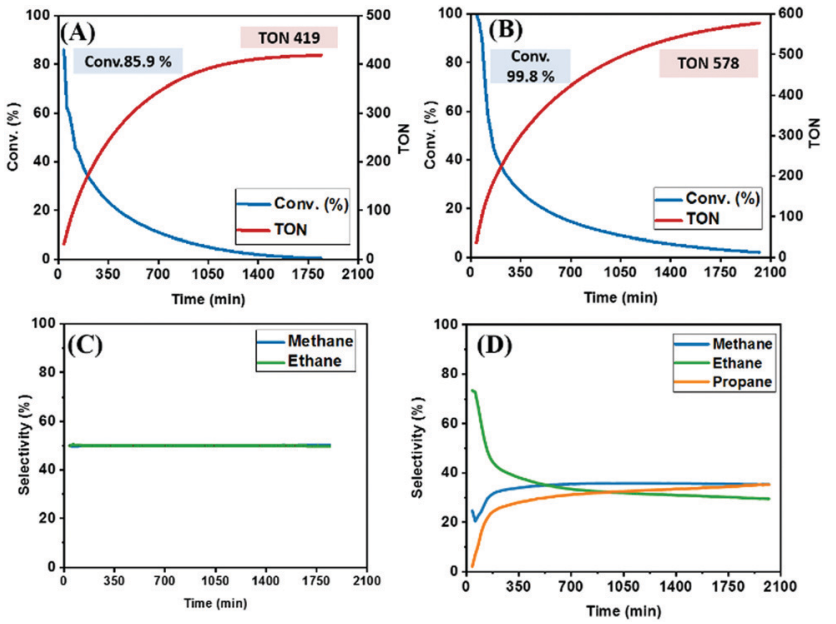

Fig. 3 Evolution of conversion (blue curve) and corresponding TON over time (red curve) for hydrogenolysis reaction of (A) propane (B) $n$-butane using 3. Evolution of product selectivities over time for hydrogenolysis reaction of (C) propane (D) $n$-butane using 3 .

$\beta$-alkyl transfer (as we observed ethane, propane, along with methane instead of only methane) followed by the formation of Ti(carbene)(alkyl) intermediate and finally, hydrogenolysis to form lower alkanes (Scheme S1, ESI $\dagger$ ). In the beginning, we observed that the selectivity for ethane is higher than other products, and ethane was considered to be the primary product. However, with time on stream, the evolution of methane and propane occurs. At the end of the reaction, we observed that the selectivity for propane, methane, and ethane remains similar. It is surprising to see that the selectivity for propane is similar to that observed for ethane and methane. We believe this is because of the low contact time of the reactant to the catalyst, and the concentration of the propane is much less to react back with the catalyst.

To our knowledge, we synthesized the first homoleptic $\mathrm{Ti}\left(\mathrm{CH}_{3}\right)_{4}$ complex without any coordinating solvent. The homogeneous complex $\operatorname{Ti}\left(\mathrm{CH}_{3}\right)_{4}$ is very reactive and starts to decompose at a temperature above $-60^{\circ} \mathrm{C}$, which makes this complex very difficult to study and use for any catalytic reaction. For the first time, it was stabilized on partially dehydroxylated silica $\left(\mathrm{SiO}_{2-700}\right)$ and was characterized at the molecular level using advanced solid-state NMR, IR and, gas quantification methods. The well-defined silica-supported pre-catalyst 3 was used for hydrogenolysis of propane and $n$-butane with a TON of 419 and 578 , respectively. Other aspects of this complex are under study in our laboratory.

\section{Conflicts of interest}

There are no conflicts to declare.

\section{Notes and references}

1 C. Bouchy, G. Hastoy, E. Guillon and J. A. Martens, Oil Gas Sci. Technol., 2009, 64, 91-112.

2 C. Gambaro, V. Calemma, D. Molinari and J. Denayer, AIChE J., 2011, 57, 711-723. 
3 J. Lee, S. Hwang, J. G. Seo, S. B. Lee, J. C. Jung and I. K. Song, J. Ind. Eng. Chem., 2010, 16, 790-794.

4 J. W. Gosselink and W. H. J. Stork, Ind. Eng. Chem. Res., 1997, 36, 3354-3359.

5 T. Hanaoka, T. Miyazawa, K. Shimura and S. Hirata, Catalysts, 2015, 5, 1983-2000.

6 J. Corker, F. Lefebvre, C. Lecuyer, V. Dufaud, F. Quignard, A. Choplin, J. Evans and J. M. Basset, Science, 1996, 271, 966-969.

7 V. R. Dufaud and J. M. Basset, Angew. Chem., Int. Ed., 1998, 37, 806-810.

8 M. K. Samantaray, E. Callens, E. Abou-Hamad, A. J. Rossini, C. M. Widdifield, R. Dey, L. Emsley and J. M. Basset, J. Am. Chem. Soc., 2014, 136, 1054-1061.

9 Y. Chen, E. Abou-hamad, A. Hamieh, B. Hamzaoui, L. Emsley and J. M. Basset, J. Am. Chem. Soc., 2015, 137, 588-591.

10 N. Maity, S. Barman, E. Callens, M. K. Samantaray, E. Abou-Hamad, Y. Minenkov, V. D'Elia, A. S. Hoffman, C. M. Widdifield, L. Cavallo, B. C. Gates and J. M. Basset, Chem. Sci., 2016, 7, 1558-1568.

11 M. K. Samantaray, E. Pump, A. Bendjeriou-Sedjerari, V. D'Elia, J. D. A. Pelletier, M. Guidotti, R. Psaro and J. M. Basset, Chem. Soc. Rev., 2018, 47, 8403-8437.

12 M. K. Samantaray, V. D’Eia, E. Pump, L. Falivene, M. Harb, S. O. Chikh, L. Cavallo and J. M. Basset, Chem. Rev., 2020, 120, 734-813.

13 M. K. Samantaray, S. Kavitake, N. Morlanes, E. Abou-Hamad, A. Hamieh, R. Dey and J. M. Basset, J. Am. Chem. Soc., 2017, 139, $3522-3527$.

14 M. K. Samantaray, R. Dey, S. Kavitake, E. Abou-Hamad, A. Bendjeriou-Sedjerari, A. Hamieh and J. M. Basset, J. Am. Chem. Soc., 2016, 138, 8595-8602.

15 J. M. Basset, C. Coperet, D. Soulivong, M. Taoufik and J. T. Cazat, Acc. Chem. Res., 2010, 43, 323-334.

16 S. Kleinhenz and K. Seppelt, Chem. - Eur. J., 1999, 5, 3573-3580.

17 H. Berthold and G. Groh, Z. Anorg. Allg. Chem., 1963, 319, 230-235.
18 H. Makio, T. Oshiki, K. Takai and T. Fujita, Chem. Lett., 2005, 34, 1382-1383.

19 H. Makio, T. Ochiai, J.-i. Mohri, K. Takeda, T. Shimazaki, Y. Usui, S. Matsuura and T. Fujita, J. Am. Chem. Soc., 2013, 135, 8177-8180.

20 Y. Gao, M. D. Christianson, Y. Wang, J. Chen, S. Marshall, J. Klosin, T. L. Lohr and T. J. Marks, J. Am. Chem. Soc., 2019, 141, 7822-7830.

21 I. E. Nifant'ev, P. V. Ivchenko, V. V. Bagrov, S. M. Nagy, S. Mihan, L. N. Winslow and A. V. Churakov, Organometallics, 2013, 32, 2685-2692.

22 D. Balboni, I. Camurati, A. C. Ingurgio, S. Guidotti, F. Focante and L. Resconi, J. Organomet. Chem., 2003, 683, 2-10.

23 M. A. Fedotov, O. L. Malkina and V. G. Malkin, Chem. Phys. Lett., 1996, 258, 330-335.

24 A. J. Rossini, R. W. Mills, G. A. Briscoe, E. L. Norton, S. J. Geier, I. Hung, S. Zheng, J. Autschbach and R. W. Schurko, J. Am. Chem. Soc., 2009, 131, 3317-3330.

25 Y. Saito, Can. J. Chem., 1965, 43, 2530-2534.

26 S. Berger, W. Bock, G. Frenking, V. Jonas and F. Mueller, J. Am. Chem. Soc., 1995, 117, 3820-3829.

27 E. S. Blaakmeer, F. J. Wensink, E. R. H. van Eck, G. A. de Wijs and A. P. M. Kentgens, J. Phys. Chem. C, 2019, 123, 14490-14500.

28 M. K. Samantaray, R. Dey, E. Abou-Hamad, A. Hamieh and J. M. Basset, Chem. - Eur. J., 2015, 21, 6100-6106.

29 Y. Chen, E. Callens, E. Abou-Hamad, N. Merle, A. J. P. White, M. Taoufik, C. Coperet, E. Le Roux and J. M. Basset, Angew. Chem., Int. Ed., 2012, 51, 11886-11889.

30 C. Rosier, G. P. Niccolai and J. M. Basset, J. Am. Chem. Soc., 1997, 119, 12408-12409.

31 S. Norsic, C. Larabi, M. Delgado, A. Garron, A. de Mallmann, C. Santini, K. C. Szeto, J. M. Basset and M. Taoufik, Catal. Sci. Technol., 2012, 2, 215-219.

32 V. Polshettiwar, F. A. Pasha, A. De Mallmann, S. Norsic, J. ThivolleCazat and J. M. Basset, ChemCatChem, 2012, 4, 363-369. 